\title{
ARE 80-YEAR-OLD SWIMMERS FASTER THAN 25-YEAR-OLD MASTER SWIMMERS?
}

\author{
Birutė Statkevičienė, Remigijus Gulbinas, Tomas Venckūnas \\ Lithuanian Academy of Physical Education, Kaunas, Lithuania
}

Birutė Statkevičienė. Doctor of Social Sciences (Education). Associate Professor at the Department of Aquatics, Lithuanian Academy of Physical Education. Research interests - Sport Anthropology, swimming history.

\begin{abstract}
Competitive sport is one of the stimulants in making people practice exercise on the regular basis. Many of the handicap systems have been tried in different sports to match younger or older competitors to the young male adults, and it seems that the result indexing system according to age, which is in operation in track-and-field at the moment, is functional enough to help motivating veteran athletes to continue to participate in sports actively. The question raised by the authors of the present study was: "How can we create and implement coefficients and equations, which may be used to compare the results achieved by the master swimmers of different age groups?". The aim of this study was to compile a point score system for the masters' swimming results.

Objectives: 1) to determine the changes in master swimmers' (men and women) race times depending on age; 2) to calculate the coefficients for the conversion of the master swimmers' (men and women) race time; 3) to offer the system of recalculation of converted master swimmers' results in time into points, and to test the new ranking system in a Master swim meet.

The data were taken from World Top-10 Masters Swimming Tabulation. Both male and female athletes were divided into 5-year age groups, starting from 25 years and going up to 94 years of age. We analysed the results (times) of the 1992-2005 year period in a cross-sectional study design. We calculated the differences in percentages of the averages of the results in different age group in comparison to the results achieved by the participants of the $25-29$ year age group. Then we calculated the age coefficients, which could be used in indexing the competitive results, and finally we applied the International Swimming Federation (FINA) tables for point score to rank the master swimmers in actual competition.

The research findings suggested that:

1. Among the women swimmers, a quicker deterioration of the results starts above the age of 75 years and older, and this decline is most obvious in breaststroke, butterfly, and individual medley, while it is less pronounced in long freestyle events.

2. For males, swimming performance also abruptly decreases after the age of 75 years. Differently from women, males degrade their freestyle sprinting abilities less than the results in long-distance freestyle swimming. The results in butterfly deteriorate the most in both genders, with the greatest decline seen again after the age of 75 years.

3. Here we have introduced a system for the recalculation of master swimmers' results by using the age coefficients, with a subsequent conversion of the result into point score. The system can be successfully applied in determining the master swimmers' rank among swimmers of different age groups.
\end{abstract}

Keywords: results of master athletes, result indexing, swimming styles.

\section{INTRODUCTION}

$\mathrm{S}$ wimming is an athletic activity in which many people of all ages participate and compete. Governed by International Swimming Federation (FINA) rules, World Swimming Championships are held for youths, adults and for veterans / masters, too. Competitions for people of those age groups are also organized in Europe. Both the long-course and short-course World championships are held biannually. Apart from physical development, psychological, technical and tactical preparations, the age of the participants is of no doubt of primary importance for the results achieved in these competitions. Whilst 25 -year-old gymnasts or swimmers are frequently called veterans, 40 -year-old yachtsmen, golfers or equestrians remain in the thick of competition and frequently win world championships or similar high-calibre events.

After the termination of athletic career, highperformance athletes frequently take a period of relative abstention from regular exercise, but later they resume their activity in sport, which is often of the same or similar kind, and which they have practiced for many years at the professional level. Many 
do this to maintain their previous physical condition; others desire to participate in competitions as veterans / masters. Competitions for veterans / masters are popular in track-and-field, basketball, cycling, and particularly in swimming. Swimming is a desirable physical activity for people of all ages because being in water they are not burdened with their weight (Organ et al., 1994). M. Goldstein and D. Tanner (1999) view swimming as advantageous over other modes of exercise and an ideal physical fitness activity for middle-aged and elderly people in respect to the quality of life. Swimming is as good and much safer than jogging provided the regimen entails at least 30 minutes three to four times per week (Ward, 1994). Swimming up to a very old age is popular in such countries as the USA, Germany, Great Britain, Canada, Japan, Italy, Sweden, and the Netherlands.

Eleven Master Swimming World Championships have been held already, and the 12th will take place in Perth (Australia) in April, 2008. Master Swimming World Championships are held in evennumbered years, while the European Swimming Championships take place on odd-numbered years. National Swimming Championships in different countries are held annually. The Master Swimming World Championships attract from 7000 to 8000 participants anywhere, approximately half of that number participate in the European Swimming Championships, and the entrants compete in 34 individual and 6 relay events (Cametti, 2004). Since the person's age has its inevitable effects, according to FINA rules, athletes are assigned to the age groups of five years, and master swimmers are those of at least 25 years of age. Thus age groups in swimming for both genders are $25-29$ years, 30-34 years, and so on.

Nessel (2004) discussed the role of age in sports performance, as well as respiratory, cardiovascular fitness; strength and body composition changes with aging; trainability of older athletes and how training can delay the decline in exercise performance. Further the author suggests that though we cannot halt "Father Time" and his inexorable march toward our decline with aging, we can fightback it to a large extent by taking up regular exercise and observing proper nutrition.

The general agreement exists that older adults can also continue or take up competitive sports provided simple precautions are taken to ensure cardiovascular health and to minimise risk of injury (Ward, 1994). There is no scientific evidence that competitive sports, swimming in particular, are detrimental to one's health, which is also true for healthy elderly people. On the contrary, it seems that greater than moderate intensity of exercise has its own additional benefits not to tell of the psychological advantages of sports activity (Trappe, 2001).

As regular participation in organised physical activity is beyond a doubt important though not easily implemented part of modern human's life, different strategies are used to persuade people to become or remain physically active. One of the stimulants is obviously competitive element of sports, which, when applied properly, may indeed be helpful in making people practice sports on the regular basis in order to be prepared for the recurrently impending competitions. Many of the handicap systems have been tried in different sports, and it seems that the point score system which is in operation in track-and-field at the moment is functional enough to help motivating veteran athletes to continue participating in sports actively. The question which the authors of the present study raised was "How can we create and implement mathematical formulas and coefficients, which may be used to compare the results achieved by Master swimmers in different age groups?" and the main (practical) aim of this study was to compile a point score system for the masters' swimming results.

\section{Objectives:}

1. To determine the changes in master swimmers' (men and women) race times depending on age.

2. To calculate the coefficients for the conversion of the master swimmers' (men and women) race time.

3. To offer the system of recalculation of converted master swimmers' results in time into points, and to test the new ranking system in a Master swim meet.

\section{ORGANIZATION OF THE STUDY}

According to FINA, master swimmers are those who are 25 years of age or older. All our studied master athletes were divided into 5-year-age groups, and thus age groups in swimming for both genders were $25-29$ years, $30-34$ years, and so on, up to the 90-94 year-old group athletes. The data on the results of the masters were taken from FINA's World Top-10 Master Swimming Tabulation. The results (times) of 1992-2005 year period were analysed in a cross-sectional study design. We calculated the averages, standard deviations, and the differences between the averages of the results of different age groups. The results in all age 
Table 1. Master swimmers' (women) race time increase (\%)

\begin{tabular}{|c|c|c|c|c|c|c|c|c|c|c|c|c|c|c|c|}
\hline \multicolumn{2}{|c|}{ Event } & $25-29$ & $30-34$ & $35-39$ & $40-44$ & $45-49$ & $50-54$ & $55-59$ & $60-64$ & $65-69$ & $70-74$ & $75-79$ & $80-84$ & $85-89$ & $90-94$ \\
\hline $50 \mathrm{~m}$ & Freestyle & 0 & 0 & 1 & 4 & 8 & 12 & 16 & 21 & 26 & 36 & 53 & 81 & 123 & 185 \\
\hline $100 \mathrm{~m}$ & Freestyle & 0 & -2 & 0 & 5 & 10 & 15 & 20 & 26 & 34 & 45 & 64 & 94 & 138 & 200 \\
\hline $200 \mathrm{~m}$ & Freestyle & 0 & -3 & -1 & 4 & 10 & 15 & 20 & 27 & 35 & 48 & 66 & 94 & 134 & 190 \\
\hline $400 \mathrm{~m}$ & Freestyle & 0 & -4 & -2 & 4 & 10 & 16 & 22 & 28 & 36 & 48 & 66 & 94 & 135 & 194 \\
\hline $800 \mathrm{~m}$ & Freestyle & 0 & -2 & -1 & 2 & 7 & 12 & 19 & 27 & 37 & 50 & 68 & 92 & 123 & 164 \\
\hline $1500 \mathrm{~m}$ & Freestyle & 0 & -2 & -1 & 2 & 7 & 14 & 21 & 31 & 42 & 55 & 69 & 87 & 108 & 132 \\
\hline $50 \mathrm{~m}$ & Breaststroke & 0 & 1 & 2 & 3 & 6 & 12 & 19 & 25 & 30 & 37 & 53 & 91 & 176 & 338 \\
\hline $100 \mathrm{~m}$ & Breaststroke & 0 & 1 & 4 & 10 & 12 & 18 & 26 & 33 & 39 & 46 & 65 & 109 & 206 & 393 \\
\hline $200 \mathrm{~m}$ & Breaststroke & 0 & 1 & 3 & 5 & 7 & 13 & 20 & 26 & 32 & 41 & 59 & 98 & 182 & 337 \\
\hline $50 \mathrm{~m}$ & Butterfly & 0 & 1 & 2 & 3 & 7 & 12 & 18 & 24 & 37 & 61 & 103 & 171 & 273 & 421 \\
\hline $100 \mathrm{~m}$ & Butterfly & 0 & 1 & 2 & 6 & 11 & 19 & 26 & 38 & 56 & 85 & 130 & 198 & 294 & 428 \\
\hline $200 \mathrm{~m}$ & Butterfly & 0 & 1 & 4 & 11 & 16 & 25 & 34 & 46 & 67 & 98 & 149 & 226 & 338 & 494 \\
\hline $50 \mathrm{~m}$ & Backstroke & 0 & 1 & 2 & 5 & 11 & 15 & 21 & 26 & 34 & 45 & 62 & 86 & 122 & 171 \\
\hline $100 \mathrm{~m}$ & Backstroke & 0 & 1 & 2 & 5 & 12 & 17 & 23 & 30 & 39 & 52 & 69 & 95 & 132 & 180 \\
\hline $200 \mathrm{~m}$ & Backstroke & 0 & 0 & 2 & 4 & 11 & 16 & 23 & 30 & 39 & 51 & 69 & 92 & 125 & 170 \\
\hline $200 \mathrm{~m}$ & $\begin{array}{l}\text { Individual } \\
\text { medley }\end{array}$ & 0 & 1 & 2 & 4 & 10 & 17 & 25 & 32 & 42 & 55 & 82 & 140 & 249 & 442 \\
\hline $400 \mathrm{~m}$ & $\begin{array}{l}\text { Individual } \\
\text { medley }\end{array}$ & 0 & 2 & 4 & 6 & 10 & 17 & 26 & 34 & 48 & 67 & 100 & 151 & 234 & 363 \\
\hline
\end{tabular}

groups above 30 were calculated as the average percentage decline in the performance (race time) in comparison to the average result of the $25-29$ year age group swimmers. The coefficients for the conversion of the result of the master swimmer into point score were obtained using approximation (best fitted curve method) from average changes (mean drops) in swimming results.

\section{RESULTS}

Swimming race results in women. The data in Table 1 show that up to 40 years of age no decline in the freestyle race performance in all the distances occured in women. We can also observe the slight improvement in the results in middle and long distance freestyle races as the second and third (30 to 39 year-aged) group female swimmers with compared to younger counterparts (aged 25 to 29).

Up to the age group of 65-69 years the results in the $50 \mathrm{~m}$ freestyle decreased by 4 to $5 \%$ every 5 years on the average, but in the 75-79 year age group the race time in the events of all distances and strokes of swimming were more than 50\% lower than those of the 25-29 year age group. Even more dramatic decline occured after the age of 80 years. An interesting tendency emerged that the oldest master swimmers were doing relatively better in long dis- tance (freestyle) than in sprint when compared to the 25-29 year age group swimmers (Table 1).

There are interesting data in butterfly, a stroke which particularly requires great strength and good joint flexibility. Comparing the $85-89$ year age group results with those of the $25-29$ year old group we detected more than $200 \%$ decrease in the race time, while the 90-94 age group masters swam butterfly on the average more than four times slower than 25-29 year old athletes. When compared with the youngest masters, fairly steep decrease in average swimming speed was obvious in the 90-94 year old age group swimmers in individual medley, which includes the butterfly.

Swimming race results in men. The results of male swimmers started to decline gradually after the age of approximately 35 years on the average, and only after the age of 45 years in long distance swimming (Table 2). However, the quick decline in male performance was evident when analysing the butterfly: the race time in the group of $75-84$ year old men more than twice outreached the results of the 25-29 year old swimmers (Table 2).

Age group coefficients. Using approximation (best fitted curve method) from average changes (mean drops) in swimming results, we obtained coefficients that were utilized for the conversion of the master swimmers' result into point score 
Table 2. Master swimmers' (men) race time increase (\%)

\begin{tabular}{|l|l|c|c|c|c|c|c|c|c|c|c|c|c|c|c|}
\hline \multicolumn{2}{|l|}{ Event } & 25-29 & $30-34$ & $35-39$ & $40-44$ & $45-49$ & $50-54$ & $55-59$ & $60-64$ & $65-69$ & $70-74$ & $75-79$ & $80-84$ & $85-89$ & $90-94$ \\
\hline $50 \mathrm{~m}$ & Freestyle & 0 & 1 & 3 & 4 & 6 & 8 & 11 & 16 & 22 & 29 & 40 & 54 & 70 & 89 \\
\hline $100 \mathrm{~m}$ & Freestyle & 0 & 1 & 2 & 4 & 7 & 10 & 14 & 19 & 26 & 35 & 48 & 66 & 88 & 120 \\
\hline $200 \mathrm{~m}$ & Freestyle & 0 & 0 & 1 & 3 & 6 & 10 & 15 & 21 & 28 & 39 & 53 & 74 & 102 & 139 \\
\hline $400 \mathrm{~m}$ & Freestyle & 0 & 0 & 1 & 4 & 8 & 12 & 16 & 22 & 29 & 40 & 56 & 82 & 120 & 172 \\
\hline $800 \mathrm{~m}$ & Freestyle & 0 & 0 & 0 & 1 & 6 & 11 & 16 & 21 & 29 & 40 & 56 & 81 & 122 & 179 \\
\hline $1500 \mathrm{~m}$ & Freestyle & 0 & 0 & 0 & 1 & 5 & 9 & 14 & 19 & 27 & 39 & 57 & 86 & 130 & 191 \\
\hline $50 \mathrm{~m}$ & Breaststroke & 0 & 0 & 3 & 6 & 10 & 14 & 17 & 21 & 26 & 35 & 47 & 67 & 95 & 136 \\
\hline $100 \mathrm{~m}$ & Breaststroke & 0 & 0 & 1 & 6 & 10 & 14 & 18 & 22 & 28 & 37 & 52 & 76 & 114 & 170 \\
\hline $200 \mathrm{~m}$ & Breaststroke & 0 & 0 & 1 & 5 & 8 & 13 & 17 & 21 & 28 & 39 & 56 & 83 & 124 & 182 \\
\hline $50 \mathrm{~m}$ & Butterfly & 0 & 0 & 2 & 6 & 9 & 12 & 15 & 20 & 28 & 44 & 70 & 113 & 177 & 269 \\
\hline $100 \mathrm{~m}$ & Butterfly & 0 & 1 & 3 & 5 & 9 & 13 & 22 & 33 & 50 & 73 & 105 & 146 & 199 & 265 \\
\hline $200 \mathrm{~m}$ & Butterfly & 0 & 1 & 3 & 6 & 10 & 17 & 25 & 38 & 54 & 76 & 106 & 143 & 189 & 245 \\
\hline $50 \mathrm{~m}$ & Backstroke & 0 & 1 & 3 & 6 & 9 & 12 & 17 & 23 & 30 & 40 & 51 & 66 & 83 & 105 \\
\hline $100 \mathrm{~m}$ & Backstroke & 0 & 0 & 4 & 8 & 13 & 18 & 23 & 28 & 35 & 46 & 62 & 86 & 120 & 168 \\
\hline $200 \mathrm{~m}$ & Backstroke & 0 & 0 & 2 & 5 & 9 & 14 & 20 & 26 & 34 & 45 & 60 & 78 & 103 & 136 \\
\hline $200 \mathrm{~m}$ & $\begin{array}{l}\text { Individual } \\
\text { medley }\end{array}$ & 0 & 0 & 1 & 4 & 7 & 11 & 17 & 24 & 34 & 48 & 66 & 92 & 127 & 175 \\
\hline $400 \mathrm{~m}$ & $\begin{array}{l}\text { Individual } \\
\text { medley }\end{array}$ & 0 & 0 & 0 & 2 & 5 & 10 & 16 & 24 & 35 & 48 & 68 & 95 & 132 & 182 \\
\hline
\end{tabular}

Table 3. Coefficients for indexing masters' swimming times (women)

\begin{tabular}{|c|c|c|c|c|c|c|c|c|c|c|c|c|c|c|c|}
\hline \multicolumn{2}{|c|}{ Event Age group, years } & $25-29$ & $30-34$ & $35-39$ & $0-44$ & $45-49$ & $50-54$ & $55-59$ & $60-64$ & $65-69$ & $70-74$ & 75-79 & $80-84$ & 85-89 & $90-94$ \\
\hline $50 \mathrm{~m}$ & Freestyle & .00 & 1.00 & 01 & .04 & 1.00 & 2 & 10 & 1.21 & 1.20 & 1.36 & 1.53 & . 01 & 2.23 & (oJ \\
\hline $100 \mathrm{~m}$ & & 00 & 0.98 & 00 & .05 & 10 & 15 & .20 & 26 & .34 & .45 & 1.64 & & 2.38 & 00 \\
\hline $200 \mathrm{~m}$ & & & & & & & & & & & & & & & 90 \\
\hline $400 \mathrm{~m}$ & & & 96 & & 04 & 10 & & 22 & & 36 & 48 & & & & 94 \\
\hline $800 \mathrm{~m}$ & & & & & & & & & & & & & & & 64 \\
\hline $1500 \mathrm{~m}$ & & & & & & & & & & & & & & & 32 \\
\hline $50 \mathrm{~m}$ & stroke & 0 & & & 3 & & 2 & .19 & 5 & 0 & .37 & 3 & & .76 & .38 \\
\hline $100 \mathrm{~m}$ & & & & & 10 & & & .26 & & & .46 & & & .06 & .93 \\
\hline $200 \mathrm{~m}$ & & & & & & & & .20 & & & & & & 32 & .37 \\
\hline $50 \mathrm{~m}$ & & & & & & & & 18 & & & & & & 73 & 21 \\
\hline $100 \mathrm{~m}$ & & & & & & & & & & & & & & & 28 \\
\hline $200 \mathrm{~m}$ & & & & & & & & & & & & & & & 43 \\
\hline $50 \mathrm{~m}$ & & & & & & & & & & & & & & & .71 \\
\hline $100 \mathrm{~m}$ & & & & & & & & & & & & & & 32 & .80 \\
\hline $200 \mathrm{~m}$ & & & & & & & & & & & & & & 25 & .70 \\
\hline $200 \mathrm{~m}$ & & & & & & & & & & & & & & 49 & .42 \\
\hline $00 \mathrm{~m}$ & & & & & 1.00 & 10 & 1.11 & 1.20 & 1.07 & 1.40 & 1.07 & 2.00 & 2.01 & 3.34 & 4.63 \\
\hline
\end{tabular}

(Fig. 1). We present all the coefficients for indexing women's results (Table 3) and all the coefficients for indexing men's results (Table 4) in swimming in all race strokes and all distances.

How to count FINA Point Score. After the recalculation of the result, the FINA Point Scoring Formula, which uses the base time for 1000 points (Swimming Top-10 Tabulation, FINA 1992-2005), can be successfully applied. The score in points (P) is calculated knowing the swim time ( $\mathrm{T}$, in seconds) and the base time (B, in seconds) by applying the following equation:

$$
\mathrm{P}=1000 \times(\mathrm{B} / \mathrm{T})^{3},
$$

i.e. the equation is used to convert time into score. Then the result is rounded to the next integer number using normal rounding $(932.499 \ldots$-> 932.50 ... - 933$)$. 
Table 4. Coefficients for indexing masters' swimming times (men)

\begin{tabular}{|c|c|c|c|c|c|c|c|c|c|c|c|c|c|c|c|}
\hline \multicolumn{2}{|c|}{ Event } & -29 & $30-34$ & -39 & $40-44$ & $45-49$ & 54 & $5-59$ & $60-64$ & $65-69$ & $0-74$ & $75-79$ & $0-84$ & $85-89$ & 90 \\
\hline$n$ & & 00 & 1.01 & . & 7 & 1.00 & 0 & & & 22 & 9 & 1.40 & T & 0 & 09 \\
\hline $100 \mathrm{~m}$ & & 00 & 1.01 & .02 & 04 & 1.07 & 10 & 14 & 1.19 & .26 & 35 & 1.48 & .66 & .88 & .20 \\
\hline $200 \mathrm{~m}$ & & & & & & & & & & 28 & & & & & 2.39 \\
\hline $400 \mathrm{~m}$ & & 00 & & 01 & 04 & 08 & 12 & & 22 & 29 & & 56 & .82 & 20 & .72 \\
\hline $800 \mathrm{~m}$ & & & & & & & & & & & & & & & 79 \\
\hline 1500 & e & & & 1.00 & & & & & & & & & & & 91 \\
\hline $50 \mathrm{~m}$ & roke & 0 & 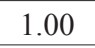 & 03 & 6 & 10 & 4 & .17 & 21 & .26 & 35 & 7 & .67 & 95 & 2.36 \\
\hline $100 \mathrm{~m}$ & eaststroke & .00 & & 1.01 & 1.06 & 10 & 1.14 & & 22 & 1.28 & .37 & & .76 & .14 & 2.70 \\
\hline $200 \mathrm{~m}$ & oke & .00 & & & 1.05 & .08 & & & & & .39 & & & .24 & 2.82 \\
\hline $50 \mathrm{~m}$ & & 00 & & & 06 & 99 & & & & 8 & 44 & & & 77 & .69 \\
\hline $100 \mathrm{~m}$ & & & & & & & & & & & & & & & 65 \\
\hline $200 \mathrm{~m}$ & & & & & & & & & & & & & & & .45 \\
\hline $50 \mathrm{~m}$ & & & & & & & & & & & & & & 83 & 2.05 \\
\hline $100 \mathrm{~m}$ & & & & & & & & & & & & & & .20 & 2.68 \\
\hline $200 \mathrm{~m}$ & & & & & & & & & & & & & & .03 & 2.36 \\
\hline $200 \mathrm{~m}$ & & & & & & & & & & ד & & & .92 & .27 & .75 \\
\hline $00 \mathrm{~m}$ & & 1.00 & .00 & 1.00 & 1.02 & 1.05 & 1.10 & 1.16 & 1.24 & 1.35 & 1.48 & 1.68 & 1.95 & 2.32 & 2.82 \\
\hline
\end{tabular}

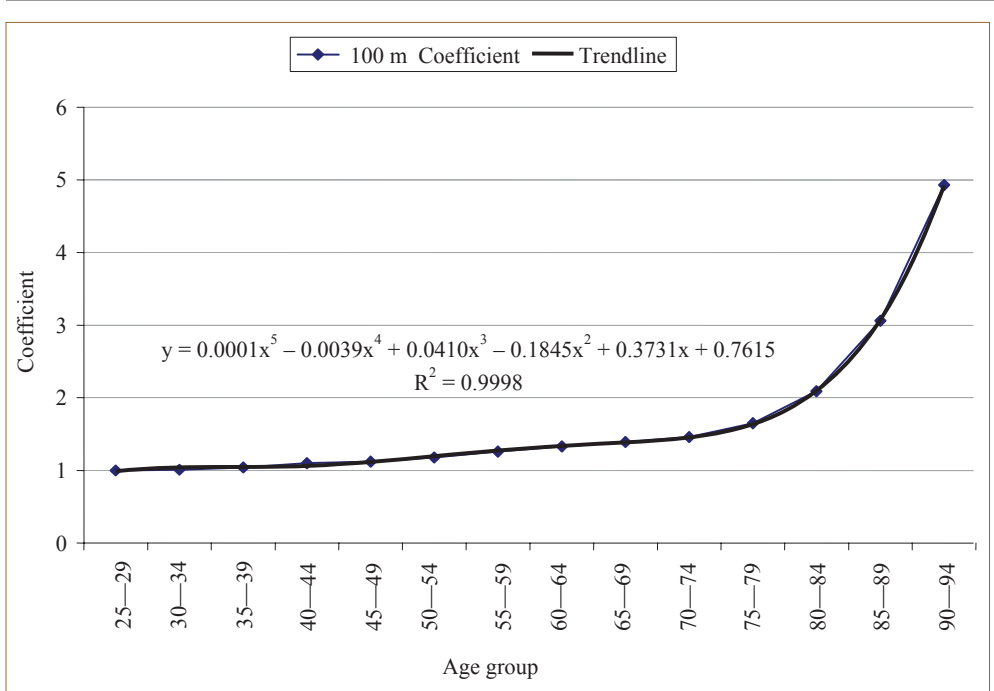

Fig. Calculated coefficients for the age groups in women's $100 \mathrm{~m}$ breaststroke

When the time ( $T$, in seconds) needed for a certain score $(\mathrm{P})$ has to be calculated, the same formula is reconstructed for the reverse calculation to yield $\mathbf{T}=\mathbf{1 0 B} \times \mathbf{P}^{-3}$. Calculated time should be rounded to one hundredth of a second.

Base times for $\mathbf{1 0 0 0}$ points as presented by FINA. The base times are set by FINA for all individual events and relays, separately for men and women as well as for the long course (Table 5) and the short course. The base times are recalculated after every Olympic Games, based on the average of the Top-10 of the All Time World Rankings. The base times are published on the FINA website within one month after the Olympics.

As an example, European Master Championship women's $50 \mathrm{~m}$ freestyle results in master age groups and their recalculation are presented in $\mathrm{Ta}-$ ble 6 . The data indicate that the quickest swimmer in the 25-29 age group was relatively slower than the 35-39 year age group champion. Recalculated results using our suggested system with the coefficients for the age groups and the corrected ratings are also presented in this example in Table 6. According to our suggested system, the $80-84$ year age group swimmer would achieve the best result in the $50 \mathrm{~m}$ freestyle event in the $2007 \mathrm{Eu}$ ropean Master Swimming Championships, and the result was obviously very high (Table 6). The second place would go to the winner of the $70-74$ year age group contest, the third - to that of the 55-59 year age group, and so on (Table 6).

Application of the system in practice. Presented point score recalculation system was applied for ranking the Top-10 swimmers at the 2006 
Table 5. Base times used in FINA points calculation for long course (2004)

\begin{tabular}{|l|l|l|l|}
\hline Distance, $m$ & Stroke & Men's time, $s$ & Women's time, $s$ \\
\hline 50 & Freestyle & 21.88 & 24.61 \\
\hline 100 & Freestyle & 48.30 & 54.01 \\
\hline 200 & Freestyle & $1: 45.94$ & $1: 57.31$ \\
\hline 400 & Freestyle & $3: 44.30$ & $4: 05.64$ \\
\hline 800 & Freestyle & $7: 48.51$ & $8: 21.84$ \\
\hline 1500 & Freestyle & $14: 48.88$ & $16: 04.14$ \\
\hline 50 & Backstroke & 25.14 & 28.50 \\
\hline 100 & Backstroke & 53.93 & $1: 00.29$ \\
\hline 200 & Backstroke & $1: 56.69$ & $2: 08.40$ \\
\hline 50 & Breaststroke & 27.51 & 31.06 \\
\hline 100 & Breaststroke & $1: 00.16$ & $1: 07.02$ \\
\hline 200 & Breaststroke & $2: 10.24$ & $2: 23.85$ \\
\hline 50 & Butterfly & 23.54 & 26.23 \\
\hline 100 & Butterfly & 51.73 & 57.65 \\
\hline 200 & Butterfly & $1: 55.14$ & $2: 06.61$ \\
\hline 200 & Individual medley & $1: 58.75$ & $2: 11.44$ \\
\hline 400 & Individual medley & $4: 12.18$ & $4: 35.82$ \\
\hline
\end{tabular}

Table 6. European Masters Swimming Championship $50 \mathrm{~m}$ freestyle champions' (women) results (2007) before and after indexing

\begin{tabular}{|l|c|c|c|c|c|c|c|c|c|c|c|c|c|}
\hline $\begin{array}{l}\text { Age groups, } \\
\text { year interval }\end{array}$ & $25-29$ & $30-34$ & $35-39$ & $40-44$ & $45-49$ & $50-54$ & $55-59$ & $60-64$ & $65-69$ & $70-74$ & $75-79$ & $80-84$ & $85-89$ \\
\hline Official time, s & 27.99 & 27.49 & 27.81 & 28.45 & 28.89 & 30.40 & 30.58 & 33.40 & 33.23 & 35.52 & 41.79 & 43.53 & 64.40 \\
\hline Rank according time & III & I & II & IV & V & VI & VII & IX & VIII & $\mathbf{X}$ & XI & XII & XIII \\
\hline Coefficient & $\mathbf{1 . 0 0}$ & $\mathbf{1 . 0 0}$ & $\mathbf{1 . 0 1}$ & $\mathbf{1 . 0 4}$ & $\mathbf{1 . 0 8}$ & $\mathbf{1 . 1 2}$ & $\mathbf{1 . 1 6}$ & $\mathbf{1 . 2 1}$ & $\mathbf{1 . 2 6}$ & $\mathbf{1 . 3 6}$ & $\mathbf{1 . 5 3}$ & $\mathbf{1 . 8 1}$ & $\mathbf{2 . 2 3}$ \\
\hline Indexed time, s & 27.99 & $\mathbf{2 7 . 4 9}$ & 27.53 & 27.36 & 26.75 & 27.14 & 26.36 & 27.60 & 26.37 & 26.12 & 27.31 & 24.05 & 28.88 \\
\hline Places after indexing & XII & IX & $\mathbf{X}$ & VIII & $\mathbf{V}$ & VI & III & XI & IV & II & VII & I & XIII \\
\hline
\end{tabular}

Table 7. Lithuanian Master Swimming Championship Top-10 swimmers (2006)

\begin{tabular}{|l|l|l|l|l|l|l|l|}
\hline Place & Gender & Stroke & Distance & Time, s & $\begin{array}{l}\text { Age group, year } \\
\text { interval }\end{array}$ & $\begin{array}{l}\text { Country represen- } \\
\text { ted }\end{array}$ & Points \\
\hline 1 & Male & Breaststroke & $50 \mathrm{~m}$ & $\mathbf{3 4 . 7 0}$ & $60-64$ & Poland & $\mathbf{1 1 6 4}$ \\
\hline 2 & Male & Backstroke & $50 \mathrm{~m}$ & $\mathbf{2 7 . 5 2}$ & $30-34$ & Lithuania & $\mathbf{1 0 5 8}$ \\
\hline 3 & Male & Backstroke & $100 \mathrm{~m}$ & $\mathbf{1 : 1 5 . 0 5}$ & $55-59$ & Russia & $\mathbf{9 8 6}$ \\
\hline 4 & Male & Breaststroke & $50 \mathrm{~m}$ & $\mathbf{3 4 . 9 2}$ & $50-54$ & Estonia & $\mathbf{9 5 5}$ \\
\hline 5 & Female & Breaststroke & $50 \mathrm{~m}$ & $\mathbf{3 7 . 3 6}$ & $35-39$ & Australia & $\mathbf{9 3 6}$ \\
\hline 6 & Male & Freestyle & $50 \mathrm{~m}$ & $\mathbf{2 4 . 9 0}$ & $25-29$ & Lithuania & $\mathbf{9 1 9}$ \\
\hline 7 & Female & Backstroke & $100 \mathrm{~m}$ & $\mathbf{1 : 2 3 . 8 6}$ & $50-54$ & Lithuania & $\mathbf{9 1 8}$ \\
\hline 8 & Female & Breaststroke & $50 \mathrm{~m}$ & $\mathbf{3 7 . 4 6}$ & $35-39$ & Lithuania & $\mathbf{8 9 6}$ \\
\hline 9 & Male & Breaststroke & $50 \mathrm{~m}$ & $\mathbf{3 4 . 5 5}$ & $45-49$ & Lithuania & $\mathbf{8 8 6}$ \\
\hline 10 & Male & Freestyle & $50 \mathrm{~m}$ & $\mathbf{2 5 . 5 2}$ & $30-34$ & Lithuania & $\mathbf{8 7 9}$ \\
\hline
\end{tabular}

Lithuanian National Open Masters Swimming Championships. According to our system, the best swimmer was the winner of the $50 \mathrm{~m}$ breaststroke in $60-64$ year age group, the second best was the 30 - 34 year group swimmer of $50 \mathrm{~m}$ backstroke, and so on (Table 7).

\section{DISCUSSION}

Our suggested master swimmers' results indexing system is simple to apply, and it may be helpful in ranking master swimmers of all catego- ries (age, gender, and event), as well as it might be used in an identification of the best swimmers of the competition, of the year, etc., as well as in lifelong activity following of the relative level of the master athlete. It may emerge as a really helpful tool in motivating the master athletes to continue their activity and maintain good health.

In their study Kolt et al. (2004) tried to identify the motivation of older people to participate in regular exercise and sports. The 815 participants (399 men) ranged in age from 55 to 93 years (mean age was 64 years) and were participating in their 
activities of choice at least once per week. The most common exercise / sports activities the participants were involved in were walking, golf, lawn bowls, tennis, and swimming. The main motives for participation were health benefits, enjoyment of the activity, better fitness, and maintenance of joint mobility (Kolt et al., 2004). Master athletes at the age of 60 can perform considerably better than some sedentary men at the age of 30 (Ward, 1994). M. Goldstein and D. Tanner (1999) view swimming as advantageous activity compared to modes of exercise and an ideal physical fitness activity for middle-aged and elderly people in respect to quality of life.

Dummer et al. (1985) examined muscle performance among 73 female master swimmers aged 24 to 71 years. Although swimming training appeared to have resulted in higher strength values for these women, an age-related decline in muscular strength values was nevertheless apparent. Their results showed different age-related trend for muscular endurance, suggesting that swim training affects muscular endurance more favourably than muscular strength among adult women. However, it was shown that master athletes spend less time per week for training, and their training focus is on endurance, not strength gains as compared to younger swimmers who train for all the endurance, strength, speed, and power, and the authors suggest that these differences might be partly responsible for age-related performance decline (Weir et al., 2002). This could be seen in the tendency of the greater decline in butterfly results in both men and women (Tables 1 and 2) in comparison to the results in other swimming disciplines. On the other hand, swimming technique is of relatively bigger importance for the results in butterfly and individual medley (which includes butterfly) than it is for the front or back crawl as separate events. In such a way, when athletes become elderly, the quicker deterioration of the results in the butterfly and medley as compared to the results in other events suggests that the motor control might become inadequate for good results in these events, while the endurance and strength are still better preserved at this stage.

Koda et al. (1994) examined forty Japanese male and female master swimmers ranging from 40 to 69 years who were selected for a comparative study of maximal oxygen uptake $\left(\mathrm{VO}_{2} \mathrm{max}\right)$. The age-related rate of decline in $\mathrm{VO}_{2}$ max was similar between genders ( 8 to $9 \%$ per decade), and in fact comparable to the values for the sedentary controls, though $\mathrm{VO}_{2}$ max in swimmers was higher than that of the age-matched sedentaries. It was concluded that swimming training might maintain a higher level of aerobic capacity, but could not prevent the decline of it with aging. On the contrary to the results in women, males do not seem to better preserve the aerobic endurance, since the race time in long distances deteriorates even quicker than that in short freestyle distances (Table 2). We can therefore conclude that older women have relatively better aerobic endurance than males of the same age.

Very few data have been published on master swimmers physiology and biomechanics. In the 162 male athletes aged $50-90$ years participating in the World Master Championships in the 200-m freestyle event, stroke length was found to decline less than stroke frequency (Gatta et al., 2006). Semi-longitudinal and cross-sectional studies indicate accelerated decline in performance starting at the age of around 60 years, and these data are further discussed by the authors in respect to the role that practice plays in performance changes due to ageing (Weir et al., 2002). In our master swimmers the most notable decline in the results was evident after the age of 75 years.

\section{CONCLUSIONS}

1. Among the women swimmers, a quicker deterioration of the results starts above the age of 75 years and older, and this decline is most obvious in breaststroke, butterfly, and individual medley, while it is less pronounced in long freestyle events.

2. For males, similarly as for women, swimming performance abruptly decreases after the age of 75 years. Differently from women, males degrade their freestyle sprinting abilities less than endurance capacity as reflected by less marked drop of the results in long-distance freestyle swimming as compared to the performance in short distance crawl. The results in butterfly deteriorate the most in both genders, with the greatest decline seen again after the age of 75 years.

3. Here we have introduced a system for the recalculation master swimmers' results by using the age coefficients, with a subsequent conversion of the result into point score. The system can be successfully applied in determining the master swimmers' rank among swimmers of different age groups. 


\title{
REFERENCES
}

Cametti, C. (2004). The greatest aquatic event ever. Internet link: http://www.fina.org/Masternews_riccione04.html

Dummer, G. M., Clarke, D. H., Vaccaro, P. et al. (1985). Agerelated differences in muscular strength and muscular endurance among female Master swimmers. Research Quarterly for Exercise \& Sport, 56, Issue 2, 97-102.

Gatta, G., Benelli, P., Ditroilo, M. (2006). The decline of swimming performance with advancing age: A cross-sectional study. Journal of Strength \& Conditioning Research, 20 (4), 932-938.

Goldstein, M., Tanner, D. (1999). Swimming for Lifetime Fitness. Saturday Evening Post, 99, Vol. 271, Issue 4, 54-81.

Koda, M., Mutoh, Y., Higuchi, M., Yoshitake, Y., Miyashita, M. (1994). Aerobic work capacity of Japanese master swimmers. Coaching \& Sport Science Journal, Vol. 1, Issue 1, 55-57.

Kolt, G. S., Driver, R. P., Giles, L. C. (2004). Why older Australians participate in exercise and sport. Journal of Aging \& Physical Activity, Vol. 12, Issue 2, 185.

Medic, N., Starkes, J. L., Young, B. W. (2001). Examining relative age effects on performance achievement and participation rates in Master athletes. Journal of Sports Sciences, Vol. 25, Issue 12, 1377-1384.

Nessel, E. H. (2004). The Physiology of Aging as it Relates to Sports. AMAA Journal, Vol. 17, Issue 2, 12-17.

Organ, L. W., Eukland A. D., Lebeter, J. D. (1994). An automated real time underwater weighing system. Medicine and Science in Sports and Exercise, Vol. 26, 3, 386-391.

Swimming Top-10 Tabulation, FINA 1992-2005. Internet link: http://www.fina.org/swimming/pdf/FINApoints/swc_ PT_formula.pdf

Trappe, S. (2001). Master athletes. Int J Sport Nutr Exerc Metab, Suppl 11, S196-207.

Ward, J. (1994). Exercise and the older person. Australian Family Physician, 23 (4), 642-645, 648-649.

Weir, P. L., Kerr, T., Hodges, N. J., McKay, S. M., Starkes, J. L. (2002). Master swimmers: how are they different from younger elite swimmers? An examination of practice and performance patterns. Journal of Aging \& Physical Activity, Vol. 10, Issue $1,41-63$.

\section{AR 80 METU AMŽIAUS PLAUKIMO VETERANAI YRA GREITESNI UŽ 25 METŲ PLAUKIMO VETERANUS?}

\author{
Birutė Statkevičienė, Remigijus Gulbinas, Tomas Venckūnas \\ Lietuvos kūno kultūros akademija, Kaunas, Lietuva
}

\begin{abstract}
SANTRAUKA
Rengimasis dalyvauti varžybose yra svarbi paskata reguliariai sportuoti. Nemažai išbandyta sistemų norint palyginti ivvairaus amžiaus sportininkų pajègumą. Viena iš tokių — šiuo metu lengvojoje atletikoje naudojama rezultatu indeksavimo pagal amžių sistema. Ją taikant galima išsamiau analizuoti rezultatų kaitą, juos palyginti Šio straipsnio autoriai iškèlè toki problemini klausimą: „Kaip sukurti ir įdiegti koeficientus, formules, pagal kurias būtų galima palyginti skirtingų amžiaus grupių plaukimo veteranų rezultatus?“. Tyrimo tikslas — sudaryti plaukimo veteranų varžybų rezultatų taškų skaičiavimo sistemą.

Uždaviniai: 1) nustatyti plaukimo veteranų (vyrų ir moterų) varžybų rezultatų kaitos priklausomumą nuo amžiaus; 2) sudaryti plaukimo veteranų (vyru ir moterų) varžybų rezultatų perskaičiavimo koeficientų lenteles; 3) pasiūlyti plaukimo veteranų varžybų perskaičiuotų rezultatų pavertimo taškais sistemą ir išbandyti siūlomą reitingų sudarymo sistemą veteranų plaukimo varžybose.

Duomenys paimti iš Pasaulio plaukimo veteranų geriausių 10 rezultatų lentelių. Vyresni nei 25 metų vyrai ir moterys buvo suskirstyti i penkerių metų intervalo amžiaus grupes. Vyriausių plaukikų amžiaus grupè - $90-94$ metai. Analizuojami $1992-2005 \mathrm{~m}$. rezultatai. Analizė atlikta palyginant tik amžiaus grupes, o $1992-2005 \mathrm{~m}$. rezultatų kaita neanalizuota. Apskaičiuotas skirtingų amžiaus grupių rezultatų vidurkio ir 25-29 metų amžiaus grupès rezultatų vidurkio procentų skirtumas, koeficientai, o perskaičiuoti rezultatai paversti taškais pagal Tarptautinès plaukimo federacijos taškų lenteles ir sistemą, taikomą veteranų plaukimo varžybose sportininkų reitingui nustatyti.

Atlikus tyrimą, galima padaryti tokias išvadas:

1. Plaukikių varžybų rezultatai sparčiau ima blogeti po 75 metų amžiaus. Šis blogejjimas labiausiai pastebimas plaukiant krūtine, peteliške ir kompleksiniu būdu, tačiau lètesnis ịveikiant ilguosius nuotolius laisvuoju stiliumi.

2. Vyru, vyresnių nei 75 metu amžiaus, sprinto rungčių rezultatai blogèja lèčiau nei moterų ilgujų nuotolių plaukimo laisvuoju stiliumi varžybose. Abieju lyčiu sporto veteranu plaukimo peteliške rezultatai blogèja greičiausiai, ypač po 75 metu amžiaus.

3. Šiame straipsnyje pateikème plaukimo veteranų rezultatus, pritaikydami mūsų sukurtus koeficientus (indeksus), paverstus taškais. Indeksuotą rezultatą verčiant taškais, galima sékmingai palyginti skirtingų amžiaus grupių sportininku, plaukimo veteranų, meistriškumą.
\end{abstract}

Raktažodžiai: plaukimo veteranų rezultatai, rezultatų indeksavimas, sportiniai plaukimo būdai.

Gauta 2007 m. rugsèjo 19 d.

Received on September 19, 2007

Priimta $2007 \mathrm{~m}$. lapkričio $15 \mathrm{~d}$.

Accepted on November 15, 2007

\author{
Birutė Statkevičiené \\ Lithuanian Academy of Physical Education \\ (Lietuvos kūno kultūros akademija) \\ Sporto str. 6, LT-44221 Kaunas \\ Lithuania (Lietuva) \\ Tel +370 37302666 \\ E-mail b.statkeviciene@lkka.lt
}

